\title{
The Relationships between Family Support, Attachment Types in Adulthood and Attitudes towards Filial Responsibility among Three Generations of Arab and Jewish Men
}

\author{
Pnina Ron \\ Senior Lecturer, Gerontologist School of Social Work, University of Haifa, Mount Carmel, Haifa, Israel \\ Email: pitzyron@research.haifa.ac.il
}

How to cite this paper: Ron, P. (2019) The Relationships between Family Support, Attachment Types in Adulthood and Attitudes towards Filial Responsibility among Three Generations of Arab and Jewish Men. Advances in Aging Research, 8, 88-106.

https://doi.org/10.4236/aar.2019.85007

Received: August 17, 2019

Accepted: September 9, 2019

Published: September 12, 2019

Copyright $\odot 2019$ by author(s) and Scientific Research Publishing Inc. This work is licensed under the Creative Commons Attribution International License (CC BY 4.0).

http://creativecommons.org/licenses/by/4.0/

\section{Open Access}

\begin{abstract}
The aim of the current study was to compare between three generations groups of Arab and Jewish male's attitudes towards filial responsibility. 121 university students, their fathers (116) and their grandfathers (114), answered a self-report questionnaire, which measured filial responsibility attitudes, type of attachment; self-esteem; sense of mastery and, family support. Results revealed ethnicity and religiosity differences as well as between-generations differences regarding filial responsibility. An additional finding brought to light the cross-generational differences in the relationship between the attachment style in adulthood and the attitudes regarding filial responsibility. The most important finding shows that the Arab male, especially in the youngest generation, finds himself in a socio-psychological-internal conflict between tradition and modernization regarding the family norms. Arab society, in attitudes towards filial responsibility, is still traditional in terms of its approach to the institutions of clan and, the men status within the family. Thus, mostly among the elderly Arab Muslims.
\end{abstract}

\section{Keywords}

Filial Responsibility, Familyism and Communalism, Types of Attachment, Attitudes and Perceptions, Intergenerational Transmission

\section{Introduction}

The "Filial responsibility" term is generally understood to refer to special duties that offspring must provide to their elderly parents beginning with the attitudes towards these obligations, services and specific actions of caring providing, etc. 
Most of the social gerontology studies of on offspring caring for their elderly parent have focused on the traditional role of daughters as the main provider [1] [2]. The general idea is that men, sons or husbands are too busy for those kinds of involvement. Yet, research based on self-reports by elderly parents finds that adult children are more likely to provide care to parent of the same gender. There is also evidence that sons are somewhat more likely than daughters to assist fathers with their daily functions [3].

Attachment refers to an internal state, a desire to be close to the figure who provides a sense of comfort and security, and whose departure creates a sense of distress. The attachment figure does not fade in adulthood; rather, the need for closeness and contact with the attachment figure exists on a symbolic level, and is addressed through thoughts and fantasies. In situations of stress, the adult child might still turn to the attachment figure for various kinds of help, ranging anywhere from financial to emotional support [4] [5] [6]. [7] found that the ways in which adult children are considerate of their parents' future needs are related to the type of attachment that was formed earlier between the adult child and the older parent. Young adults still see their parents as a source of support and seek parental advice, thus preserving to a certain extent the parent's function as an attachment figure. Later in life, both the child and the parent shift their security base to other sources and figures, spouses and partners, in the majority of cases [8]. Another process that is likely to take place is a change in the direction of the attachment relationship, such that the children, who used to rely on the parents for security and support, become a source of security and support for their parents (Krause \& Haverkamp, 1996; Grundy \& Henretta, 2006; Merz et al., 2008) [8] [9] [10].

The type of attachment is perceived as the intersection of two orthogonal dimensions: attachment anxiety and attachment avoidance. An anxiety attachment style predicts caring for the elderly parent [11]. Adult children with an anxiety attachment type demonstrate a higher degree of willingness to provide future care for the parent [5] [7]. It was also found that this attachment type increases the tendency of adult children to protect, care and attend to their elderly parents [6]. Yet, as regards the anxiety type of attachment, findings are mixed. Some claim that no association was found between adult children's anxiety attachment type and either current or planned future care for elderly parents [6]. In contrast, there are researchers who have found a positive connection between anxiety attachment and caring for an elderly parent, albeit these cases demonstrated the provision of low-quality care. Anxiety attachment is an obstacle to the rendering of care for the elderly parent, and inappropriate care could be caused by self-centered anxieties experienced by the anxious adult child related to the shifting of attention from the self to the attachment figure [6] [12] [13].

Attachment avoidance refers to the degree to which a person fails to trust or feels suspicious and uncomfortable in close situations and consequently maintains a physical and emotional distance from the attachment figures. The avoidance attachment type was found consistently to have a negative association with 
caring for elderly parents [13] [14] and negatively associated with the desire to provide future care [6]. The discomfort felt by adults with this attachment type, their avoidance of intimacy, their exaggerated self-reliance, and their lack of empathy moderate the ability to provide responsive and sensitive care [15] [16].

The current study focuses on additional variables that are mentioned in the literature as related to and influencing adult children's tendency to provide help and support to their older parents. These variables are the intrapersonal variables (sense of mastery, self-esteem) and the interpersonal variable of family support.

Sense of mastery is the degree to which a person perceives having control over changes and life events [17]. The research literature indicates the existence of a positive relationship between one's sense of mastery over life events and the extent and quality of the care offered to one's older parents [18].

Self-esteem is one component within the concept of the self. Rosenberg defined it as encompassing the thoughts and feelings individuals have when perceiving themselves as objects [19]. A high sense of self-esteem was found to be related to higher levels of perceived mental wellbeing among adults caring for their family members compared to the levels found among adults who were not caring for family members [2] [20].

Among the informal sources of interpersonal support, the literature presents family, friends, and significant others as significant sources of support. Family support has been shown to have positive effects on mental wellbeing, on physical and mental health, and on adaptability [2] [21].

Norms and filial attitudes are relevant to people in any stage of adulthood, from adolescence to old age. Hence, there is variance among the norms and attitudes, which stems from-among other variables-social characteristics, such as age, education and the family status of the adult children as well as that of their parents. In addition, the research literature has identified social characteristics that differentiate people [22].

Studies of recent years have investigated intercultural differences in perceptions of adult children's filial responsibility for caring for elderly parents. Thus, it was found that in collectivist cultures such as those found in China and in Hong-Kong as well as in traditional societies the entire family is responsible for caring for elderly parents within the household [23], rather than through an institutional arrangement [24]. Despite the effects of modernization processes on the Arab family structure, for the most part, it is the daughters and daughters-in-law, and occasionally the granddaughters, who in fact care for the elderly family member [25]. Yet, it should be noted that the brightened responsibility to take care of the elderly parents is on the eldest son shoulders, especially among the traditional rural Muslim Arabs.

Given this information, the research attempt to learn and determine the relationship between the attitudes towards filial responsibility and the attachment type in adulthood among three generations of Jewish and Arab men. This, while taking into account demographic characteristics such as education, religiosity, 
etc., as well as the interpersonal variables of sense of mastery, self-esteem, and the intrapersonal variable of family support.

The research had two hypotheses: 1) Differences will be found between the Jewish and the Arab men's levels of family support and their attitudes towards filial responsibility regarding their anxiety type of attachment in adulthood. 2) Differences will be found between the elderly parents' generations and the other two generations' levels of family support and their attitudes towards filial responsibility regarding their anxiety type of attachment in adulthood.

\section{Methods}

\subsection{Population and Sample}

The research participants were 121 Jewish and Arab university male students studying for an undergraduate or a graduate degree at the University of Haifa, Israel (the adult grandchildren generation), their parents (the adult parents' generation, $\mathrm{N}=116$ ) and their grandparents (the elderly parents generation $\mathrm{N}=$ 114) reaching a total number of 351 participants. The sample was a convenience sample. Questionnaires which were not entirely completed (5 of the father's generation and 7 of the grandfather's generation) were excluded out from the sample. Each student was given a set of three identical questionnaires: one for self-use by the student himself, one to be completed by the student's father and one to be completed by the student's grandparent. All three gyrations' participants have got the same questionnaires. The participants answered the questionnaires by themselves. If anyone needed any help, the student helped them.

The age range of the adult grandchildren group was between 22 and 36 years old. The adult parents' generation age range was between 40 - 67 years old, and in the elderly parents' generation, that of the grandparents, ages range from 64 to 86 years old. Additional demographic characteristics are presented in Table 1.

Some interesting findings are shown in Table 1. For example, among the Jewish sample there were no Orthodox participants while among the Arab sample both the eldest (53\%) and the youngest (48\%) participants reported themselves as Orthodox. The sense of mastery and the self-esteem variables' average score was the highest among both the Jewish and the Arab youngest generation. Among the three Arab generations the level of filial responsibility was found to be higher than among the Jewish three generations. In the current table, regarding the attachment type variable, only the highest score of the two scores (anxiety score and avoidance score) was emphasized.

\subsection{Research Tools}

Attitudes towards filial responsibility were measured using The Expectations of Filial Responsibility Scale developed by [26]. This questionnaire contains 16 items that describe filial behaviors of adult children towards his/her parents. Participants are asked to rank the degree to which they agree with the statements, using, on a Likert-like scale ranging from $1=$ "completely disagree" to 
Table 1. Background characteristics of the three study's generations Jewish $\mathrm{N}=199$; Arab $\mathrm{N}=152$ ).

\begin{tabular}{|c|c|c|c|c|c|c|c|c|c|c|c|c|}
\hline \multirow{4}{*}{ Variable } & \multicolumn{4}{|c|}{ Elderly Parents $(\mathrm{N}=114)$} & \multicolumn{4}{|c|}{ Adult Children (116) } & \multicolumn{4}{|c|}{ Adult Grandchildren $N=117$ ) } \\
\hline & \multirow{2}{*}{\multicolumn{2}{|c|}{$\begin{array}{l}\text { Jewish } \\
(\mathrm{N}=65)\end{array}$}} & \multirow{2}{*}{\multicolumn{2}{|c|}{$\begin{array}{c}\text { Arab } \\
(\mathrm{N}=49)\end{array}$}} & \multirow{2}{*}{\multicolumn{2}{|c|}{$\begin{array}{c}\text { Jewish } \\
(\mathrm{N}=65)\end{array}$}} & \multirow{2}{*}{\multicolumn{2}{|c|}{$\begin{array}{c}\text { Arab } \\
(\mathrm{N}=51)\end{array}$}} & \multirow{2}{*}{\multicolumn{2}{|c|}{$\begin{array}{c}\text { Jewish } \\
(\mathrm{N}=69)\end{array}$}} & \multirow{2}{*}{\multicolumn{2}{|c|}{$\begin{array}{c}\text { Arab } \\
(\mathrm{N}=52)\end{array}$}} \\
\hline & & & & & & & & & & & & \\
\hline & $\mathrm{N}$ & $\%$ & $\mathrm{~N}$ & $\%$ & $\mathbf{N}$ & $\%$ & $\mathbf{N}$ & $\%$ & $\mathbf{N}$ & $\%$ & $\mathbf{N}$ & $\%$ \\
\hline \multicolumn{13}{|l|}{ Family Status } \\
\hline Married/living with a spouse & 52 & 80.0 & 41 & 83.6 & 46 & 70.7 & 42 & 82.3 & 23 & 34.1 & 29 & 55.7 \\
\hline Not married/living with a spouse & 13 & 20.0 & 8 & 16.4 & 19 & 29.3 & 9 & 17.7 & 42 & 65.9 & 23 & 44.3 \\
\hline \multicolumn{13}{|l|}{ Religiosity } \\
\hline Orthodox & - & - & 26 & 53.0 & - & - & 16 & 31.3 & - & - & 25 & 48.0 \\
\hline Conservative & 24 & 36.9 & 13 & 26.5 & 25 & 38.4 & 14 & 27.4 & 22 & 33.8 & 13 & 25.0 \\
\hline Observant & 41 & 63.1 & 10 & 20.5 & 40 & 61.6 & 21 & 41.3 & 43 & 66.2 & 14 & 27.0 \\
\hline \multicolumn{13}{|l|}{ Style of Living } \\
\hline City (small/big) & 55 & 84.6 & 8 & 16.3 & 53 & 81.5 & 10 & 19.6 & 56 & 86.1 & 13 & 25.0 \\
\hline \multirow[t]{2}{*}{ Rural (village/community) } & 10 & 15.4 & 41 & 83.7 & 12 & 18.5 & 40 & 80.4 & 9 & 13.1 & 39 & 75.0 \\
\hline & $\mathbf{M}$ & SD & $\mathbf{M}$ & SD & $\mathbf{M}$ & SD & $\mathbf{M}$ & SD & $\mathbf{M}$ & SD & $\mathbf{M}$ & $\mathrm{SD}$ \\
\hline Age (in Years) & 73.4 & 6.2 & 67.4 & 8.5 & 53.1 & 7.1 & 49.1 & 5.1 & 26.8 & 6.7 & 22.6 & 3.2 \\
\hline Education (in Years) & 11.4 & 5.1 & 6.9 & 4.2 & 14.9 & 4.3 & 10.9 & 2.8 & 16.0 & 2.8 & 14.2 & 1.0 \\
\hline Filial Responsibility 1 - 5 & 4.4 & 0.5 & 4.8 & 0.3 & 3.6 & 0.9 & 4.2 & 0.7 & 3.8 & 0.9 & 4.6 & 0.4 \\
\hline Sense of Mastery 1 - 5 & 3.3 & 1.0 & 3.2 & 0.7 & 3.5 & 0.5 & 3.6 & 0.5 & 4.3 & 0.4 & 4.0 & 0.6 \\
\hline Self-Esteem 1 - 5 & 3.5 & 0.7 & 3.1 & 0.8 & 4.1 & 0.6 & 3.7 & 0.4 & 4.3 & 0.3 & 4.2 & 0.5 \\
\hline Family Support $1-7$ & 5.6 & 1.1 & 5.4 & 0.6 & 5.2 & 0.7 & 5.9 & 0.6 & 6.1 & 0.7 & 6.2 & 0.4 \\
\hline \multicolumn{13}{|l|}{ Type of Attachment $1-7$} \\
\hline Avoidance type & - & - & 6.1 & 1.1 & - & - & 6.2 & 0.9 & 5.2 & 0.8 & - & - \\
\hline Anxiety type & 5.8 & 0.7 & - & - & 5.7 & 0.4 & - & - & - & - & 5.9 & 0.5 \\
\hline
\end{tabular}

5 = "very much agree". The tool's reliability in the current study was between 0.89 and 0.93 Cronbach's alpha for the three participating generations.

Type of attachment was examined using the questionnaire of [27]: Experiences in Close Relationships (ECR) Scale. The questionnaire was translated into Hebrew by [16]. It includes 36 items, which create two scales representing the two dimensions: anxiety (18 items, e.g., "I'm afraid of being abandoned") and avoidance (18 items, e.g., "I prefer not to let other people know how I feel inside"). Participants are asked to rank the degree to which they agree with the statement, using a seven-point Likert-like scale ranging from $1=$ "disagree completely" to 7 = "agree completely". Two scores are calculated for each of the participants: one for the anxiety dimension and one for the avoidance dimension, so that a high score indicates an attachment type characterized by a high degree of anxiety or avoidance. The reliability of this tool in the current study was between 0.82 and 0.86 Cronbach's alpha for the avoidance dimension, and between 0.85 and 0.93 Cronbach's alpha for the anxiety dimension, for participants from all three generations.

Sense of Mastery was measured using the scale of [28]. The scale includes seven items, on which participants indicate the degree to which they agree with 
the given statements: $1=$ strongly disagree and $5=$ strongly agree. A high average score indicates a strong sense of mastery. Reliability of the original scale was 0.82 Cronbach's alpha, whereas, in the current study, internal reliability was 0.87 Cronbach's alpha.

Self-esteem was measured using the Rosenberg scale of self-esteem [19]. The questionnaire consists of ten items, ranked on a Likert-like scale ranging from $1=$ disagree completely, to $5=$ agree completely. Five of the items relate to positive feelings regarding self-esteem, such as "I feel I have several good qualities", and five items relate to negative feelings regarding self-esteem, such as "in general, I tend to consider myself a failure". The overall ranking is calculated according to the item averages, such that a high ranking corresponds to a high level of self-esteem. The questionnaire was translated into Hebrew by [28], who reported reliability rates between 0.88 Cronbach's alpha and 0.91 Cronbach's alpha.

Familial support. This variable was measured using the Multi-Dimensional Scale of Perceived Social Support (MS PSS), which was introduced by [29] to measure familial support. The scale includes 12 items referring to three sources of support: family, friends, and significant others. In the current study, only the section on familial support was used. On each item, participants are asked indicate the degree to which the statement corresponds to their feelings, using a seven-point Likert-like scale ranging from 1 = "extremely different from the way I feel", to 7 = "closely corresponds to the way I feel". Participants' scores were calculated as the average of rankings for all items. Reliability of this scale in the current study was between 0.90 and 0.94 Cronbach's alpha, for participants from all three generations.

\subsection{Procedure}

The current study was approved by the Ethics Committee of Haifa University (May 2017). The goals of the study were explained to the students, and they all signed an informed consent form, which included a written description of the research, its aims and significance, as well as anonymity and confidentiality clauses. Trios of three generations questionnaires that did not include in the current study were from reason such: the questionnaires did not come back completely finished by one or more of the generations. In the end, the study included 351 participants.

About half of the questionnaires were translated to Arabic and then the accuracy of the translation was verified using the back-translation method. The questionnaires were completed using the self-report method: hence, and when necessary, the youngest generation members helped their older relatives understand the questions.

\section{Results}

The statistical procedures in the current study were conducted via SPSS includ- 
ing frequencies measurements, correlations between the study variables (for example-matrix of Pearson correlations), and also three models of two-step hierarchical regression were conducted, etc.

The differences between the three generations participants and among the two ethnicity groups were examined using $\chi^{2}$ and ANOVA followed by Scheffe post-hoc comparison when appropriate. The differences between the Jewish and the Arab participants are shown separately in Table 2 and Table 3.

As the table shows, among the Jewish generations, the level for levels of attitudes towards filial responsibility was higher among the elderly parents' generation than in the other two generations. Yet, and surprisingly, the level of family support among the participants in the youngest generation was higher than the other two generations. The participants in the Jewish youngest generations reported higher scores for each of the internal variable such sense of mastery and self-esteem. In addition, the youngest generation members reported about avoidance type of attachment in adulthood than did the other two generations.

Finding related to the Arab three generations participants were found to be, in general, and as was accepted, somehow different than the findings related to the Jewish one. The highest level of filial responsibility was reported by the elderly

Table 2. Differences between the Jewish three generations background characteristics $(\mathrm{N}=199)$.

\begin{tabular}{|c|c|c|c|c|c|c|c|}
\hline \multirow[t]{2}{*}{ Variable } & \multicolumn{2}{|c|}{$\begin{array}{l}\text { Elderly Parents } \\
\qquad(\mathrm{N}=65)\end{array}$} & \multicolumn{2}{|c|}{$\begin{array}{l}\text { Adult Children } \\
\qquad(\mathrm{N}=65)\end{array}$} & \multicolumn{2}{|c|}{$\begin{array}{l}\text { Adult Grandchildren } \\
\qquad(\mathrm{N}=69)\end{array}$} & \multirow{2}{*}{$x^{2}$} \\
\hline & $\mathbf{N}$ & $\%$ & $\mathrm{~N}$ & $\%$ & $\mathbf{N}$ & $\%$ & \\
\hline \multicolumn{8}{|l|}{ Family Status } \\
\hline Married/living with a spouse & 52 & 80.0 & 46 & 70.7 & 23 & 34.1 & 0.77 \\
\hline Not married/living with a spouse & 13 & 20.0 & 19 & 29.3 & 42 & 65.9 & \\
\hline \multicolumn{8}{|l|}{ Religiosity } \\
\hline Orthodox & - & - & - & - & - & - & \multirow{3}{*}{4.77} \\
\hline Conservative & 24 & 36.9 & 25 & 38.4 & 22 & 33.8 & \\
\hline Observant & 41 & 63.1 & 40 & 61.6 & 43 & 66.2 & \\
\hline \multicolumn{8}{|l|}{ Style of Living } \\
\hline City (small/big) & 55 & 84.6 & 53 & 81.5 & 56 & 86.1 & \multirow[t]{2}{*}{5.25} \\
\hline \multirow[t]{2}{*}{ Rural (village/community) } & 10 & 15.4 & 12 & 18.5 & 9 & 13.9 & \\
\hline & $\mathbf{M}$ & SD & $\mathbf{M}$ & SD & $\mathbf{M}$ & SD & \multirow{4}{*}{$19.88^{* *}$} \\
\hline Type of Attachment 1 - 7 & & & & & & & \\
\hline Avoidance type & & & & & 5.2 & 0.8 & \\
\hline \multirow[t]{2}{*}{ Anxiety type } & 5.8 & 0.7 & 5.7 & 0.4 & & & \\
\hline & $\mathbf{M}$ & SD & $\mathbf{M}$ & SD & $\mathbf{M}$ & SD & F \\
\hline Age (in Years) & 73.4 & 6.2 & 53.1 & 7.1 & 26.8 & 6.7 & $\mathbf{F}_{(3,217)}=31 \cdot 19^{*}$ \\
\hline Education (in Years) & 11.4 & 5.1 & 14.9 & 4.3 & 16.0 & 2.8 & $\mathbf{F}_{(2,665)}=7.4$ \\
\hline Filial Responsibility 1 - 5 & 4.4 & 0.5 & 3.6 & 0.9 & 3.8 & 0.9 & $\mathbf{F}_{(2,665)}=16.22^{* * *}$ \\
\hline Sense of Mastery 1 - 5 & 3.3 & 1.0 & 3.5 & 0.5 & 4.3 & 0.4 & $\mathbf{F}_{(2,665)}=7.32^{\star \star}$ \\
\hline Self-Esteem 1 - 5 & 3.5 & 0.5 & 4.1 & 0.6 & 4.3 & 0.3 & $\mathbf{F}_{(2,762)}=12 \cdot 12^{\star *}$ \\
\hline Family Support 1 - 7 & 5.6 & 1.1 & 5.2 & 0.7 & 6.1 & 0.7 & $\mathbf{F}_{(2,665)}=8.21^{\star}$ \\
\hline
\end{tabular}

${ }^{*} \mathrm{p}<0.05 ;{ }^{* *} \mathrm{p}<0.01 ;{ }^{* * *} \mathrm{p}<0.001$. 
Table 3. Differences between the Arab three generations background characteristics $(\mathrm{N}=152)$.

\begin{tabular}{|c|c|c|c|c|c|c|c|}
\hline \multirow[t]{2}{*}{ Variable } & \multicolumn{2}{|c|}{$\begin{array}{l}\text { Elderly Parents } \\
\qquad(\mathrm{N}=49)\end{array}$} & \multicolumn{2}{|c|}{$\begin{array}{l}\text { Adult Children } \\
\qquad(\mathrm{N}=51)\end{array}$} & \multicolumn{2}{|c|}{$\begin{array}{l}\text { Adult Grandchildren } \\
\qquad(\mathrm{N}=52)\end{array}$} & \multirow{2}{*}{$x^{2}$} \\
\hline & $\mathrm{N}$ & $\%$ & $\mathbf{N}$ & $\%$ & $\mathbf{N}$ & $\%$ & \\
\hline \multicolumn{8}{|l|}{ Family Status } \\
\hline Married/living with a spouse & 41 & 83.6 & 42 & 82.3 & 29 & 55.7 & 2.00 \\
\hline Not married/living with a spouse & 8 & 16.4 & 9 & 17.7 & 24 & 44.3 & \\
\hline \multicolumn{8}{|l|}{ Religiosity } \\
\hline Orthodox & 26 & 53.0 & 16 & 31.3 & 25 & 48.0 & \multirow{3}{*}{$11.56^{* *}$} \\
\hline Conservative & 13 & 26.5 & 14 & 27.4 & 13 & 25.0 & \\
\hline Observant & 10 & 20.5 & 21 & 41.3 & 14 & 27.0 & \\
\hline \multicolumn{8}{|l|}{ Style of Living } \\
\hline City (small/big) & 8 & 16.3 & 10 & 19.6 & 13 & 25.0 & \multirow[t]{2}{*}{$6.66^{*}$} \\
\hline \multirow[t]{2}{*}{ Rural (village/community) } & 49 & 83.7 & 40 & 80.4 & 39 & 75.0 & \\
\hline & $\mathbf{M}$ & SD & $\mathbf{M}$ & SD & $\mathbf{M}$ & SD & \multirow{4}{*}{$23.71^{* * *}$} \\
\hline Type of Attachment 1 - 7 & & & & & & & \\
\hline Anxiety type & 6.1 & 1.1 & 6.2 & 0.9 & & & \\
\hline \multirow[t]{2}{*}{ Avoidance type } & & & & & 5.9 & 0.5 & \\
\hline & $\mathbf{M}$ & SD & $\mathbf{M}$ & SD & $\mathbf{M}$ & SD & F \\
\hline Age (in Years) & 67.4 & 8.5 & 49.1 & 5.1 & 22.6 & 3.2 & $\mathbf{F}_{(2,781)}=27.92^{\star}$ \\
\hline Education (in Years) & 6.1 & 4.1 & 11.7 & 4.1 & 16.2 & 1.0 & $\mathbf{F}_{(2,733)}=11.17$ \\
\hline Filial Responsibility 1 - 5 & 4.8 & 0.3 & 4.2 & 0.7 & 4.6 & 0.4 & $\mathbf{F}_{(2,733)}=32.86^{* * *}$ \\
\hline Sense of Mastery 1 - 5 & 3.2 & 0.7 & 3.7 & 0.5 & 4.3 & 0.5 & $\mathbf{F}_{(2,733)}=7.24^{*}$ \\
\hline Self-Esteem 1 - 5 & 3.7 & 0.8 & 3.9 & 0.7 & 4.2 & 0.7 & $\mathbf{F}_{(2,733)}=6.89^{\star *}$ \\
\hline Family Support 1 - 7 & 5.8 & 0.8 & 6.0 & 0.9 & 6.2 & 0.4 & $\mathbf{F}_{(2,733)}=3.93$ \\
\hline
\end{tabular}

${ }^{*} \mathrm{p}<0.05 ;{ }^{* *} \mathrm{p}<0.01 ;{ }^{* * *} \mathrm{p}<0.001$.

parent and the youngest generations. Surprisingly, the youngest generation's members reported of the highest level of family support in comparison to the other two generations.

Because one focus of the study was assessment of whether attachment type in adulthood, social support and other variables contribute to the attitude towards filial responsibility, we examined the association between all of the research variables. We examined it for the Jewish and for the Arab participants separately. The findings in the two procedures were pretty much the same so we decided to present it verbally. Conducting a Matrix of Pearson correlations between the study's variables have shown that most of the study's variables were significantly associated to each other both among the Jewish and the Arab samples.

The filial responsibility variable among the Jewish participants was significantly associated with most of the study's variables except the age (generation variable) $(\mathrm{r}=0.28)$, the education $(\mathrm{pr}=-0.11)$ and the religiosity $(\mathrm{r}=0.08)$ variables. The filial responsibility variable was highly positively significantly associated with the anxiety type of attachment variable ( $\mathrm{pr}<0.83$; $\mathrm{p}<0.001)$ and with the family support $(\mathrm{r}<0.64 ; \mathrm{p}<0.001)$.

The filial responsibility variable among the Arab participants was significantly 
associated with most of the study's variables except the age (generation variable) $(\mathrm{r}=0.078)$ and the education $(\mathrm{p}<-0.09)$ variables. The filial responsibility variable was highly positively significantly associated with the avoidance type of attachment variable $(\mathrm{r}<0.44 ; \mathrm{p}<0.001)$ and with the family support $(\mathrm{r}<0.17$; $<<$ 0.05).

To answer the research question regarding the contribution of the type of attachment in adulthood and the family support variables to the men's levels of filial responsibility, we conducted three models of two-step hierarchical regression for the Jewish sample and the Arab sample separately. In the first step, all the independent variables were entered into the regression equation in all three models. The second step was different for each of the models: In the first model, the type of attachment in adulthood was entered into the regression equation; in the second model, the family support variable was entered into the regression equation; and in the third, both type of attachment in adulthood and family variables were entered. The findings are shown in Table 4 \& Table 5.

Table 4. Two steps hierarchical regression of family support and type of attachment among the Jewish sample.

\begin{tabular}{|c|c|c|c|c|c|c|}
\hline \multirow[b]{2}{*}{ Variables } & \multicolumn{3}{|c|}{ Step 1} & \multicolumn{3}{|c|}{ Step 2} \\
\hline & $B$ & $S E$ & $B$ & $B$ & $S E$ & $B$ \\
\hline Religiosity & 0.041 & 0.072 & $0.146^{*}$ & 0.034 & 0.019 & 0.411 \\
\hline Sense of Mastery & 0.065 & 0.046 & $0.129^{* *}$ & 0.058 & 0.050 & $0.189^{*}$ \\
\hline Self-Esteem & 0.055 & 0.040 & $0.121^{\star}$ & 0.051 & 0.039 & $0.173^{*}$ \\
\hline Age (Generation) & 0.037 & 0.029 & $0.155^{\star *}$ & 0.032 & 0.023 & $0.161^{\star}$ \\
\hline Family Support & & & & 0.062 & 0.087 & $0.436^{* * *}$ \\
\hline$F$ & \multicolumn{3}{|c|}{$17.228^{\star * *}(\mathrm{df}=7.034)$} & \multicolumn{3}{|c|}{$21.802^{\star * *}(\mathrm{df}=10.501)$} \\
\hline$F$ Change & & & & \multicolumn{3}{|c|}{$23.470^{\star * *}(\mathrm{df}=2.994)$} \\
\hline$R 2$ & \multicolumn{3}{|c|}{0.296} & \multicolumn{3}{|c|}{0.324} \\
\hline$R 2$ Change & & & & \multicolumn{3}{|c|}{0.179} \\
\hline Religiosity & 0.041 & 0.072 & $00.146^{*}$ & 0.135 & 0.046 & 0.237 \\
\hline Sense of Mastery & 0.065 & 0.046 & $0.129^{* *}$ & 0.040 & 0.032 & $0.100^{\star}$ \\
\hline Self-Esteem & 0.055 & 0.040 & $0.121^{\star}$ & 0.071 & 0.61 & $0.748^{\star}$ \\
\hline Age (Generation) & 0.037 & 0.029 & $0.155^{\star *}$ & 0.033 & 0.084 & $0.169^{\star}$ \\
\hline Anxiety Type of Attachment & & & & 0.090 & 0.041 & $0.375^{\star * *}$ \\
\hline$F$ & \multicolumn{3}{|c|}{$17.228^{\star * *}(\mathrm{df}=7.034)$} & & & \\
\hline \multicolumn{7}{|l|}{$F$ Change } \\
\hline$R 2$ & & 0.296 & & & & \\
\hline \multicolumn{7}{|l|}{$R 2$ Change } \\
\hline Religiosity & 0.041 & 0.072 & $0.146^{\star}$ & 0.045 & 0.013 & 0.189 \\
\hline Sense of Mastery & 0.065 & 0.046 & $0.129^{* *}$ & 0.031 & 0.012 & $0.163^{*}$ \\
\hline Self-Esteem & 0.055 & 0.040 & $0.121^{\star}$ & 0.071 & 0.038 & 01.94 \\
\hline Age (Generation) & 0.037 & 0.029 & $0.155^{\star *}$ & 0.038 & 0.033 & $0.187^{\star}$ \\
\hline Family Support & & & & 0.048 & 0.027 & $0.428^{* * *}$ \\
\hline
\end{tabular}




\section{Continued}

\begin{tabular}{|c|c|c|c|c|}
\hline Anxiety Type of Attachment & & 0.254 & 0.045 & $0.312^{\star * *}$ \\
\hline$F$ & $17.228^{* * *}(\mathrm{df}=7.034)$ & \multicolumn{3}{|c|}{$24.398^{\star * \star}(\mathrm{df}=12.326)$} \\
\hline$F$ Change & & \multicolumn{3}{|c|}{$30.007^{\star * *}(\mathrm{df}=11.299)$} \\
\hline$R 2$ & 0.296 & \multicolumn{3}{|c|}{0.512} \\
\hline$R 2$ Change & & \multicolumn{3}{|c|}{0.211} \\
\hline
\end{tabular}

${ }^{*} \mathrm{p}<0.05 ;{ }^{* *} \mathrm{p}<0.01 ;{ }^{* * *} \mathrm{p}<0.001$.

Table 5. Two steps hierarchical regression of family support and type of attachment among the Arab sample.

\begin{tabular}{|c|c|c|c|c|c|c|}
\hline \multirow[b]{2}{*}{ Variables } & \multicolumn{3}{|c|}{ Step 1} & \multicolumn{3}{|c|}{ Step 2} \\
\hline & $B$ & $S E$ & $B$ & $B$ & $S E$ & $B$ \\
\hline Religiosity & 0.057 & 0.083 & $0.065^{\star}$ & 0.047 & 0.032 & $0.097^{\star}$ \\
\hline Sense of Mastery & 0.044 & 0.072 & $0.096^{\star * *}$ & 0.049 & 0.079 & $0.126^{\star * *}$ \\
\hline Self-Esteem & 0.037 & 0.022 & $0.015^{\star}$ & 0.033 & 0.084 & 0.011 \\
\hline Age (Generation) & 0.053 & 0.087 & $0.090^{* *}$ & 0.103 & 0.092 & $0.170^{\star *}$ \\
\hline Family Support & & & & 0.204 & 0.058 & $0.334^{* * *}$ \\
\hline$F$ & \multicolumn{3}{|c|}{$16.774^{\star * *}(\mathrm{df}=7.111)$} & \multicolumn{3}{|c|}{$19.038^{\star * *}(\mathrm{df}=9.505)$} \\
\hline$F$ Change & & & & \multicolumn{3}{|c|}{$22.226^{\star \star *}(\mathrm{df}=3.740)$} \\
\hline$R 2$ & \multicolumn{3}{|c|}{0.302} & \multicolumn{3}{|c|}{0.402} \\
\hline$R 2$ Change & & & & \multicolumn{3}{|c|}{0.198} \\
\hline Religiosity & 0.057 & 0.083 & $0.065^{\star}$ & 0.183 & 0.019 & $0.230^{*}$ \\
\hline Sense of Mastery & 0.044 & 0.072 & $0.096^{* * *}$ & 0.067 & 0.018 & $0.414^{* * *}$ \\
\hline Self-Esteem & 0.037 & 0.022 & $0.015^{\star}$ & 0.094 & 0.052 & 0.396 \\
\hline Age (Generation) & 0.053 & 0.087 & $0.090^{* *}$ & 0.138 & 0.095 & $0.147^{\star *}$ \\
\hline Avoidance type of attachment & & & & & 0.035 & $0.398^{* * *}$ \\
\hline$F$ & \multicolumn{3}{|c|}{$16.774^{\star * *}(\mathrm{df}=7.111)$} & \multicolumn{3}{|c|}{$23.505^{\star * *}(\mathrm{df}=11.229)$} \\
\hline$F$ Change & & & & \multicolumn{3}{|c|}{$26.911^{\star \star *}(\mathrm{df}=9.758)$} \\
\hline$R 2$ & \multicolumn{3}{|c|}{0.302} & \multicolumn{3}{|c|}{0.447} \\
\hline$R 2$ Change & & & & \multicolumn{3}{|c|}{0.195} \\
\hline Religiosity & 0.057 & 0.083 & $0.065^{\star}$ & 0.037 & 0.012 & $0.106^{*}$ \\
\hline Sense of Mastery & 0.044 & 0.072 & $0.096^{* * *}$ & 0.061 & 0.027 & $0.94^{* *}$ \\
\hline Self-Esteem & 0.037 & 0.022 & 0.015 & 0.045 & 0.040 & 0.107 \\
\hline Age (Generation) & 0.053 & 0.087 & $0.090^{* *}$ & 0.039 & 0.029 & $0.080^{* *}$ \\
\hline Family Support & & & & 0.031 & 0.021 & $0.322^{* * *}$ \\
\hline Avoidance Type of Attachment & & & & 0.254 & 0.048 & $0.303^{\star * *}$ \\
\hline$F$ & \multicolumn{3}{|c|}{$16.774^{\star * \star}(\mathrm{df}=7.111)$} & \multicolumn{3}{|c|}{$22.390^{\star * *}(\mathrm{df}=13.207)$} \\
\hline$F$ Change & & & & \multicolumn{3}{|c|}{$25.140^{\star * *}(\mathrm{df}=10.544)$} \\
\hline$R 2$ & \multicolumn{3}{|c|}{0.302} & \multicolumn{3}{|c|}{0.496} \\
\hline$R 2$ Change & & & & \multicolumn{3}{|c|}{0.313} \\
\hline
\end{tabular}

${ }^{*} \mathrm{p}<0.05 ;{ }^{* *} \mathrm{p}<0.01 ;{ }^{* *} \mathrm{p}<0.001$ 
Table 4 shows that all three models regarding the Jewish sample were statistically significant findings. The family support variable added $44 \%$ to the explained variance of the filial responsibility and the anxiety type of attachment in adulthood variable added about $38 \%$ to the explained variance of the filial responsibility and when both of them were entered the anxiety type of attachment in adulthood added about $31 \%$ and the family support variable added about $43 \%$.

Table 5 shows that all three models regarding the Arab sample were statistically significant findings. The family support variable added about $33 \%$ to the explained variance of the filial responsibility and the avoidance type of attachment in adulthood variable added about $40 \%$ to the explained variance of the filial responsibility. When both of them were entered the avoidance type of attachment in adulthood added about $30 \%$ and the family support variable added about $32 \%$.

\section{Discussion}

Findings revealed cultural-ethnicity differences between the Jewish and the Arab participants regarding the attitudes towards filial responsibility, attachment type in adulthood, family support, etc. Finding also revealed intergenerational differences between those two ethnicity groups.

Regarding the cultural-ethnicity differences, findings show that the Arab population reported the strongest positive attitudes toward filial responsibility among all three generations especially among the youngest generation. The Arab population was also found to be with higher levels of family support in comparison to the Jewish two generations participants: the middle and the youngest generations. Yet, when we conducted the two-step hierarchical regression, the family support variable among the Arab population was found to be a weaker contributor in comparison to the same contributor among the Jewish participants.

The phenomenon of filial responsibilities among family members in traditional societies is well known. In general, the head of the traditional family, including the Arab family, is the eldest male figure (grandparent, parent, uncle, etc.) and he is expected to be the "anything for everyone" or the figure in charge on the extended family. A comprehensive study conducted among Arab families in Israel found that adult children's filial responsibility towards their parents was very high [30] and among the middle generation, it was the highest. The researcher found that despite processes of urbanization, modernization, and offspring's exodus from the villages in search of employment, filial responsibility of Arab participants in terms of caring for elderly parents was relatively high compared to that demonstrated in other studies involving Jewish participants. This was particularly true about Muslim Arabs (compared to Christian Arabs and Druse) and religious (compared to secular) participants living in northern Israel. In the current study, the highest level of filial responsibility was found 
among the elderly parents generation ( 4.8 from 5 ) and in the second place was the youngest generation (4.6 from 5 ).

Over the past century have not changed and repaired infrastructure the patriarchal Arab culture. Those norms, among other norms, included the masculine men members' role in the family. Men will always be the head of the clan even when he is not educated and has not any lidding qualities. His role is to be in charge of the family members and to the elderly and the vulnerable members among them. He does not have to do the ordinary daily tasks himself but he will be responsible that someone, usually the feminine family members will provide it. Those long years of tradition might have their influence on the way attitudes towards filial responsibility are intergenerational transmitted.

The traditional role within the family expects adult suns to take care of their elderly parent even if it only by their attitudes towards the filial responsibly. The practice of the caring belongs to the women as in most of the Western societies including the Jewish society in Israel [2]. In the current study, the Jewish adult children generation participants (e.g. the sons of the elderly parents) were holding the lowest level of positive attitudes towards the filial responsibly (3.9 from 5).

We can use some explanations for these phenomena among both the Arab and the Jewish population. For example, adult sons may have seen their fathers mentioned over the years, how important are to take care for an elderly parent and via intergenerational transmission; they transmitted it to their own sons [2]. If the adult sons have seen some other way of behaving by their fathers the possibility is that they will transmit this particular behaving they have seen to their own sons.

Another explanation for the positive attitudes towards the filial responsibility can be that participants in this generation are already more aware to their role of care providing to their children and maybe their own grandchildren and the filial responsibility is just another task for them in function or only as their attitudes. Men can assume that by their positive attitudes towards filial responsibility they are playing a role model for their children and when the time will come, their sons will hold the same attitudes. Examination of the correlation between gender role orientation and emotional well-being regarding filial responsibility found that masculinity, in general, is strongly correlated with a high level of adjustment and positive attitudes and a low level of depression.

The current study finding also indicated that the elderly parents' generation both Jewish and Arab, held positive attitudes towards the filial responsibility. The simplest explanation for this result is the issue of age. The older a person gets, the more aware he/she becomes of the possibility that sometime in the future one may need the help of others, and that family members are the natural candidates for providing this assistance [31].

Given that the Arab men, in all three generations demonstrated similar levels of attitudes towards filial responsibility, it is safe to assume that the dynamic of 
intergenerational transmission played an important role in yielding these findings. The term "intergenerational transmission" is used to describe a broad spectrum of family relationships. Researchers have used it to refer to the process of transference of attitudes, believes, values, psychological characteristics and, behavior patterns from one generation to the next, which creates intergenerational similarities [26]. This type of transmissions are either family-specific or are influenced by the family's culture, religion, ethnicity, etc. [27]. Other researchers have found that various interpersonal characteristics, such as self-identity, self-esteem, and intergenerational dependence [32], are subject to intergenerational transmission; even moods [26]. The major theories on intergenerational transmission, among them those that follow the behavioral approach [33] [34], the family approach [31] [35], and the psychoanalytic approach [36] [37], all agree on this essential definition. The behavioral theories emphasize the process of modeling and reinforcement as a major type of learning in which children not only experience but also observe and listen to the behaviors of central figures in their lives [38]. It is also the theory of choice for explicating the findings of the current study. Children who repeatedly hear their parents say that it is the son and daughter responsibility to take care of the elderly parent, will have the same attitude and approach when they become young adults and elderly people. They too will be of the opinion that adult children are obligated to take care of their parents. It may be assumed that residential proximity and frequent family gatherings, especially as is typical of religiously traditional families, such the rural, Arab families, increase the effects of intergenerational transmission.

However, the most interesting finding in the current study belongs to the youngest Arab generation. Their scores in all study variables regarding attitudes and family were much similar to the grandparents' generation than to their parent generation. The intergenerational transmission theory can't be an explanation for this phenomenon and those finding need some more studies to explore and try to explain it.

Most of the studies that deal with gender-based intergenerational transmission emphasize the transmission of behaviors, rather than transmission of attitudes or stereotypes. There are very few gender-based intergenerational transmission studies in general, and those that consider intergenerational transmission of attitudes towards filial responsibility are even fewer. It is suggested that additional studies be conducted in order to understand the effects of gender on intergenerational transmission in regards to various attitudes.

Another finding in the current study that demonstrated an intergenerational difference was in the relationship between the attachment type and the attitudes towards filial responsibility. It was found that those generations' members with the anxiety attachment type exhibited the strongest positive attitudes regarding filial responsibility. Among all generation, both Jewish and Arab participants the scores were the opposite: The elderly Jewish generation reported on anxiety type of attachment while the Arab elderly parent generation reported an avoidance 
type of attachment, etc.

Given that there are only a few studies on the attachment type of the elderly (perhaps because their attachment figures have already passed on), and poorly studies involving men attachment type, it is possible that the explanation offered in [5] study could be pertinent in this study. Cicirelli drew a distinction between attachments and affection, and claimed that "although they are related, attachment and affection are not synonymous concepts. Nevertheless, most existing studies of adult attachment in relation to caregiving have used measures of affection to represent attachment" ([5], pp. 145). In the current study, the findings of significant correlation between anxiety attachment type and high positive level attitudes towards filial responsibility in the Jewish elderly parents' generation can be used as an attempted to expand [5] idea and offer an explanation that relates to the absence of a live attachment figure among the elderly parents' generation (one of the elderly parents or in the way they use to be where they were younger to their children who are now adult parents themselves). Thus, it is suggested that the demise of the attachment figure and the continued feelings towards such a figure, it is possible that the men of the elderly parent generation shifted the feelings they had for their attachment figures onto their offspring. This shift is manifested in the way that they express emotions towards their children or in their attitudes towards filial responsibility. Clearly, this explanation must be examined in future studies. Among the Arab elderly parent's generation, because of the fact that the Arab population live fewer years than the Jewish population, this explanation is not relevant.

The literature does not provide any certain differences between men and women regarding the attachment type in adulthood. A little attention to men attachment type was given for emphasizing the association between an attachment type and mental health issues such early separation anxiety in men with eating disorders [38], clinical depression [35], adjustment in men and women with HIV/AIDS [39], etc. As noted in the literature review, the patterns of attachment type are based on mental representations, positive and negative of the self and of the other, which are located on a continuum that includes the dimensions of avoidance and anxiety [27] [33]. Those men and/or women with an anxiety attachment type are characterized by a positive attitude towards self and others, whereas those with an avoidance attachment style demonstrate a more positive attitude towards the other than towards the self. In an attempt to explain the effect identified in the study, a comparison between these two attachment types is warranted. The common denominator between the two attachment types is a positive attitude towards the other, which enables the development of intimacy, and a dependence on the other, and thus there is no avoidance of closeness. Nonetheless, among those with an anxiety attachment type, this closeness is the outcome of despair and separation anxiety [33]. It is possible that a positive perception of the other may explain the stronger attitudes towards filial responsibility indicated by participants with this attachment type [36]. 
As the individual matures, and the need for closeness and contact with the attachment figure becomes more symbolic, a situation of distress is likely to cause this person to turn to the attachment figure. Providing assistance to the parents is considered a protecting behavior. Whether the assistance is limited to the conceptual level, as in feelings, a sense of filial responsibility or it is manifested in practice-and perhaps constitutes a burden, the very act of providing such assistance enables the adult child (middle generation member) to protect the attachment figure from danger. In this context, strong positive attitudes towards filial responsibility may reflect the attempts of adult children with an anxiety attachment type to preserve their source of security and diminish their fear of separation [6].

Regarding the motives for caring for an elderly parent, it was indicated that care provided by an individual with an anxiety attachment type derives from self-focused anxiety regarding the shift of attention from self to the attachment figure [12] [13]. Those findings have shown a motivation for caregiving based on egotistical considerations, given the limited ability of those with anxiety attachment type to provide support, which requires a degree of empathy for others. The gap between attitudes and actual caring behavior in general, may explain the current study's finding of particularly strong positive attitudes towards filial responsibility among individuals with anxiety attachment types. Similarly, future studies may be able to determine whether mediating variables also affect (and if so, to what extent) the willingness of those with an avoidance attachment type to provide future care for the elderly relative.

The impact of the variable of ethnicity on filial norms and caring for older parents has been widely investigated in the literature [37] [40] [41]. In traditional Arab society-and to some extent this has not changed-the extended family functions as a single system, a clan, a collective structure in which the group or family identity plays a central role [42]. According to the collectivist norms of Arab society, especially among the Muslim society, the children (mostly daughters and daughters in low) are responsible for caring for their elderly parents; this manifests in the existence of a broad family network that supports and keeps its elderly members within the home [30] [43].

In the current study, the religiosity was found to be one of the predictors of the positive attitudes towards the filial responsibility among the Arab three generations members. No Jewish Orthodox participants were included in the current study and the religiosity variable didn't found to be a predictor of the positive attitudes towards the filial responsibility among any of the Jewish three generation participants. Among the Arab participants it was found that as the participant is younger, the more Orthodox he becomes. It seems that among the Israeli Arab-Muslim society, practicing the religion is a major factor in the family life and to take care of an elderly parent in a social norm as well as a religion norm.

Findings of the current study are supported by an additional study which recently examined the role of intergenerational solidarity and filial norms and its 
effect on quality of life, while comparing a cohort of adult Jews and adult Arabs in Israel [41] [44]. When caring for an elderly parent, families of both ethnicities face the same challenges, although the ways in which families cope and the solutions that they find tend to differ. The researchers found that Arab adults are more likely to receive support from their family members in the hour of need, because of the family structure, the norms, and the social, religious and financial resources. The comparison regarding the variable of intergenerational solidarity and support for an elderly parent revealed various similarities and differences, which are related to the culture and to family values, as well as to the personal resources.

Another interesting finding pertaining to the three generations members was a positive relationship between family support and attitudes towards filial responsibility especially among the adult Arab grandchildren generation. These findings are the opposite to the assumption that the rise in life expectancy, the increased percentage of physically limited elderly people, the fracturing of the extended family into independent nuclear families, etc. will decline the levels of family support among the youngest generation. Yet, it seems that in last two decades, the Arab younger generation is getting closer to their extend families socially and emotionally. It may be because of the need to balancing between the competitive-cold-world outside and the supportive-cozy-world within the family. It also may be connected to the fact that young Arab people are becoming closer to their religion all over the world and actually, we can see a parallel process of modernization on the one hand and getting back to tradition and old norms on the other hand [36] [44].

\section{Limitations and Suggestions}

The limitations of this study related to the sample and sampling of the research. The youngest group of participants is all students in the University of Haifa and it may have some influence on the research results especially among the Arab young generation' participants. It is suggested to continue the research in other Israeli areas and among the young population age group that is not Universities students.

\section{Conflicts of Interest}

The author declares no conflicts of interest regarding the publication of this paper.

\section{References}

[1] Pillemer, K. and Suitor, J.J. (2002) Explaining Mothers' Ambivalence toward Their Adult Children. Journal of Marriage and Family, 64, 602-613.

https://doi.org/10.1111/j.1741-3737.2002.00602.x

[2] Ron, P. (2009) Daughters as Caregivers of Aging Parents: The Shattering Myth. Journal of Gerontological Social Work, 52, 135-153.

https://doi.org/10.1080/01634370802561943 
[3] Campbell, L.D. and Martin-Matthews, A. (2003) The Gendered Nature of Men's Filial Care. Journal of Gerontology. Social Sciences, 58, 350-358. https://doi.org/10.1093/geronb/58.6.S350

[4] Cicirelli, V.G. (2010) Relation of Educational Level, Internality, and Health Status to Older Adults' Self Health Care. 63rd Annual Scientific Meeting of the Gerontological Society of America, New Orleans, 16 March 2010, 1-14.

[5] Cicirelli, V.G. (1993) Attachment and Obligation as Daughters' Motives for Caregiving Behavior and Subsequent Effect on Subjective Burden. Psychology and Aging, 8, 144-155. https://doi.org/10.1037/0882-7974.8.2.144

[6] Karantzas, G.C., Evans, L. and Foddy, M. (2010) The Role of Attachment in Current and Future Parent Caregiving. Journal of Gerontology. Psychological Sciences, 65, 573-580. https://doi.org/10.1093/geronb/gbq047

[7] Sörensen, S., Webster, J.D. and Roggman, L.A. (2002) Adult Attachment and Preparing to Provide Care for Older Relatives. Attachment and Human Development, 4, 84-106. https://doi.org/10.1080/14616730210123102

[8] Merz, E.M., Schuengel, C. and Schulze, H.J. (2008) Inter-Generational Relationships at Different Ages: An Attachment Perspective. Ageing and Society, 28, 717-736. https://doi.org/10.1017/S0144686X08007046

[9] Krause, A.M. and Haverkamp, B.E. (1996) Attachment in Child-Older Parent Relationships: Research, Theory and Practice. Journal of Counseling and Development, 75, 83-92. https://doi.org/10.1002/j.1556-6676.1996.tb02318.x

[10] Grundy, E. and Henrietta, J.C. (2006) Between Elderly Parents and Adult Children: A New Look at the Intergenerational Care Provided by the "Sandwich Generation". Ageing and Society, 26, 707-722. https://doi.org/10.1017/S0144686X06004934

[11] Cicirelli, V.G. (1983) A Measure of Filial Anxiety Regarding Anticipated Care of Elderly Parent, The Gerontologist, 28, 478-482. https://doi.org/10.1093/geront/28.4.478

[12] Feeney, J.A. and Hohause, L. (2001) Attachment and Spousal Caregiving. Personal Relationships, 8, 21-39. https://doi.org/10.1111/j.1475-6811.2001.tb00026.x

[13] Collins, N.L. and Feeney, B.C. (2000) A Safe Haven: An Attachment Theory Perspective on Support Seeking and Caregiving in Intimate Relationships. Journal of Personality and Social Psychology, 78, 1053-1073. https://doi.org/10.1037/0022-3514.78.6.1053

[14] Carpenter, B.C. (2001) Attachment Bonds between Adult Daughters and Their Older Mothers: Associations with Contemporary Caregiving. Journal of Gerontology: Psychological Sciences, 56, 257-266. https://doi.org/10.1093/geronb/56.5.P257

[15] Gillath, O., Shaver, P.R., Mikulincer, M., Nitzberg, R.E., Erez, A. and Van Ijzendoorn, M.H. (2005) Attachment, Caregiving and Volunteering: Placing Volunteerism in an Attachment-Theoretical Framework. Personal Relationships, 12, 425-446. https://doi.org/10.1111/j.1475-6811.2005.00124.x

[16] Mikulincer, M. and Shaver, P.R. (2007) Attachment Patterns in Adulthood: Structure, Dynamics and Change. Guilford Press, New York.

[17] Lachman, M.E. and Weaver, S.L. (1998) The Sense of Control as Moderator of Social Class Differences in Health and Well-Being. Journal of Personality and Social Psychology, 74, 763-773. https://doi.org/10.1037/0022-3514.74.3.763

[18] Skaff, M., Pearlin, L.I. and Mullen, J.T. (1996) Transitions in Caregiving Career: Effects on Sense of Mastery. Psychology and Aging, 11, 247-257. https://doi.org/10.1037/0882-7974.11.2.247 
[19] Rosenberg, M. (1965) Society and the Adolescent Self-Image. Princeton University Press, Princeton. https://doi.org/10.1515/9781400876136

[20] Chappell, N.L. and Reid, R.C. (2002) Burden and Well-Being among Caregivers: Examining the Distinction. Gerontologist, 42, 772-780. https://doi.org/10.1093/geront/42.6.772

[21] Cohen, S. and Wills, T. (1985) Stress, Social Support and the Buffering Hypothesis. Psychological Bulletin, 98, 310-337. https://doi.org/10.1111/bjhp.12035

[22] Silverstein, M. and Gans, D. (2006) Intergenerational Support to Aging Parents: The Role of Norms and Needs. Journal of Family Issues, 27, 1068-1084. https://doi.org/10.1177/0192513X06288120

[23] Ting, G.H.Y. and Woo, J. (2009) Elder Care: Is Legislation of Family Responsibility the Solution? Asian Journal of Gerontology and Psychiatry, 4, 72-75.

[24] Al-Haj, M. (1995) Kinship and Modernization in Developing Societies: The Emergence of Instrumentalized Kinship. Journal of Comparative Family Studies, 26, 311-328.

[25] Navaie-Waliser, M., Spriggs, A. and Feldman, P.H. (2002) Informal Caregiving: Differential Experiences by Gender. Medical Care, 40, 1249-1259. https://doi.org/10.1097/00005650-200212000-00012

[26] Hamon, R.R. and Blieszner, R. (1990) Filial Responsibility Expectations among Adult Children-Older Parent Pairs. Journal of Gerontology, 45, 110-112. https://doi.org/10.1093/geronj/45.3.P110

[27] Brennan, K.A., Clark, C.L. and Shaver, P.R. (1998) Self-Report Measurement of Adult Attachment: An Integrative Overview. In: Simpson, J.A. and Rholes, W.S., Eds., Attachment Theory and Close Relationships, Guilford, New York, 46-76.

[28] Hobfoll, S.E. and Walfisch, S. (1984) Coping with a Threat to Life: A Longitudinal Study of Self-Concept, Social Support, and Psychological Distress. American Journal of Community Psychology, 12, 87-100. https://doi.org/10.1007/BF00896930

[29] Zimet, G.D., Dahlem, N.W., Zimet, S.G. and Farey, G.K. (1988) The Multidimensional Scale of Perceived Social Support. Journal of Personality Assessment, 52, 30-41. https://doi.org/10.1207/s15327752jpa5201_2

[30] Halayla, R. (2008) Modernization and Filial Piety towards Elderly Parents in Arab Society in Israel. PhD Dissertation, Hebrew University of Jerusalem, Jerusalem. (In Hebrew)

[31] Fingerman, K.L., Sechrist, J. and Birditt, K.S. (2013) Changing Views on Intergenerational Ties. Gerontology, 59, 64-70. https://doi.org/10.1159/000342211

[32] Leopold, T. and Raab, M. (2013) The Temporal Structure of Intergenerational Exchange: A Within-Family Analysis of Parent-Child Reciprocity. Journal of Aging Studies, 27, 252-263. https://doi.org/10.1016/j.jaging.2013.05.001

[33] Bartholomew, K. and Horowitz, L.M. (1991) Attachment Styles among Young Adults: A Test of a Four-Category Model. Journal of Personality and Social Psychology, 61, 226-244. https://doi.org/10.1037/0022-3514.61.2.226

[34] Mikulincer, M. and Florian, V. (2000) Exploring Individual Differences in Reactions to Mortality Salience: Does Attachment Style Regulate Terror Management Mechanisms? Journal of Personality and Social Psychology, 79, 260-273. https://doi.org/10.1037//0022-3514.79.2.260

[35] Bifulco, A., Moran, P.M., Ball, C. and Bernazzani, O. (2002) Adult Attachment Style: Its Relationship to Clinical Depression. Social Psychiatry and Psychiatric Epidemiology, 37, 50-59. https://doi.org/10.1007/s127-002-8215-0 
[36] Ron, P. (2016) The Relationship between Attachment Styles in Adulthood and Attitudes Regarding Filial Responsibility among Three Generations of Arab Families. Psychology, 7, 741-752. https://doi.org/10.4236/psych.2016.76077

[37] Pinquart, M. and Sorensen, S. (2006) Gender Differences in Caregiver Stressors, Social Resources, and Health: An Updated Meta-Analysis. Journals of Gerontology. Series B (Psychological Sciences and Social Sciences), 61, 33-45. https://doi.org/10.1093/geronb/61.1.P33

[38] Trois, A., Massaroni, P. and Cuzzlaro, M. (2005) Early Separation Anxiety and Adult Attachment Style in Women with Eating Disorders. British Journal of Clinical Psychology, 44, 89-97. https://doi.org/10.1348/014466504X20053

[39] Turner-Cobb, J., Gore-Felton, C., Marouf, F., Koopman, C., et al. (2002) Coping, Social Support and Attachment Style as Psychosocial Correlators of Adjustment in Men and Women with HIV/AIDS. Journal of Behavioral Medicine, 25, 337-352. https://doi.org/10.1023/A:1015814431481

[40] Sung, K.T. (1998) Exploration of Action of Filial Piety. Journal of Aging Studies, 12, 369-386. https://doi.org/10.1016/S0890-4065(98)90025-1

[41] Lowenstein, A. and Kats, R. (2000) Rural Arab Families Coping with Cargiving. Marriage \& Family Review, 30, 179-197. https://doi.org/10.1300/J002v30n01_11

[42] Barakat, H. (1993) The Arab World: Society, Culture, and State. University of California Press, Berkeley.

[43] Haj-Yahia, M.M. (1995) Toward Culturally Sensitive Intervention with Arab Families in Israel. Contemporary Family Therapy, 17, 429-447.

https://doi.org/10.1007/BF02249355

[44] Ron, P. (2015) Intergenerational Transmission of Attitudes towards Poverty in Israel: A Comparison between Three Generations Families' of Jewish and Arab Social Work Students. International Journal of Social Science Studies, 3, 21-29.

https://doi.org/10.11114/ijsss.v3i3.719 